\title{
Women's Role in Economic Development of Afghanistan
}

\author{
Shahla Hamidi ${ }^{1, *}$, Suraya Hamidi ${ }^{2}$ \\ ${ }^{1}$ Department of Molecular Biology, Faculty of Nursing, Kabul Medical University, Kabul, Afghanistan \\ ${ }^{2}$ Department of Pedagogy, Faculty of Psychology and Educational Science, Kabul University, Kabul, Afghanistan
}

\section{Email address:}

Shahla.hamidi786@yahoo.com (Shahla H.), afghan_ecucation@yahoo.com (Suraya H.)

*Corresponding author

\section{To cite this article:}

Shahla Hamidi, Suraya Hamidi. Women's Role in Economic Development of Afghanistan. Science Journal of Business and Management. Vol. 8, No. 1, 2020, pp. 1-6. doi: 10.11648/j.sjbm.20200801.11

Received: October 22, 2019; Accepted: December 25, 2019; Published: January 7, 2020

\begin{abstract}
Throughout the history, the central role of women in society has ensured the stability, progress and development of nations. The women of Afghanistan, a country that passed 4 decades of war, but still they are taking part in making our beloved Afghanistan a better place. Economic development of a country is something which requires a collective work with diligence, honesty, talent, knowledge, leadership, discipline and above all a motivated and inspired sum of people specially women. Being a woman in a country which traditions come first is something which makes it very difficult for playing the role effectively. Women's economic empowerment refers to the ability for women to enjoy their right to control and benefit from the resources, assets, income and their own time, as well as the ability to manage risk and improve their economic status and well-being. In this paper, the role of women in economic development of Afghanistan will be explained point by point by using primary and secondary data from reliable and accurate resources plus, programs and workshops for women economic empowerment and the barriers and obstacles faced by them as well.
\end{abstract}

Keywords: Promote, Obstacles, World Bank, Women Empowerment, Economic Development

\section{Introduction}

Women as the half of the society are playing a very vital role in economic development of Afghanistan. Despite notable progress in rebuilding the economy, strengthening institutions, and restoring infrastructure and basic services, Afghanistan faces tremendous challenges today.

Afghanistan has relatively successfully managed the immediate challenges resulting from the political transition post-election of 2014. The country has maintained macroeconomic stability and established the conditions for a slow recovery of the economy. Risks to the economy remain significant, however, and withdrawal of international security forces starting 2011, coupled with political uncertainties and declining aid, have resulted in deceleration of economic growth, while fiscal pressures increase as security threats mount.

The latest numbers from the Afghanistan Living Conditions Survey (ALCS) released by the National Statistics and Information Authority (NSIA) (previously the Central Statistics Organization) show that poverty in
Afghanistan has increased from $38.3 \%$ in $2012-13$ to 54.5 percent in 2016-17.2 With the population continuing to grow more than 3\% a year, per capita GDP fell during the same period from US\$ 669 to US\$ 551, making it one of the poorest countries in the world. At the same time, private sector growth has fallen $9.4 \%$ in the period $2003-2012$ to only $2.1 \%$ between 2013 and 2016 .

Private sector development and diversification is constrained by political instability, weak institutions, inadequate infrastructure, widespread corruption, and a difficult business environment (Afghanistan was ranked 183rd of 190 countries in the 2018 Doing Business Survey and 177 out of 180 in Transparency International's 2017 Corruption Perception Index) With a fresh election cycle approaching in 2018-19, it is vital that the GOIRA focuses on private sector led growth and revitalization of the economy to fill up the void emerging from declining donor inflows.

The role of women in economic development of Afghanistan is such a vital phenomenon where even a "filmmaker named Delphine Renou profiles a new generation of Afghan women standing up for rights long withheld by 
previous regimes. From police officers to boxers, these women present the new face of Afghanistan, as they take part in street art, rap songs, and even driving [1]."

A particularly concerning challenge is the low level of economic empowerment of Afghan women. The current level of women's formal economic contribution to Afghan development is low. While women constitute 47 percent of the estimated 34.65 million population of Afghanistan in 2016 the female labour force participation rate stands at only 26.8 percent (down from 29 percent in 2013-14). Among working age women, only 29 percent are economically active and most are employed in the agricultural sector ( 70 percent) while 24 percent are in manufacturing.

While the Constitution of the Islamic Republic of Afghanistan clearly states that "the citizens of Afghanistan whether man or woman - have equal rights and duties before the law" 6 and while most commercial laws have no explicit gender-legal differentiations (e.g. women can own and register businesses, open bank accounts, etc.), there are implicit cultural barriers and lack of legal incentive mechanisms that reduce the ability of women to participate in the economy successfully.

"The economics profession includes disproportionately few women and members of historically underrepresented racial and ethnic minority groups, relative both to the overall population and to other academic disciplines. This underrepresentation within the field of economics is present at the undergraduate level, continues into the ranks of the academy, and is barely improving over time [2]."

Women are half the body of society. In most of developing countries as Afghanistan; they are also the most vulnerable part, but still they are playing a crucial role in economic development of the country. This research was conducted to analyze the role of women in economic development of Afghanistan, to point out and explain current obstacles faced by Afghan women, for explaining the programs and workshops for Afghan women economic empowerment and at last to suggest recommendations and solutions for the current barriers and obstacles faced by Afghan women.

\section{Research Methodology}

A comprehensive plan is required to start any research or project. A clear idea of research procedure has to be presented as the value of any systematic and standard research lies in its methodology and the validity of data used in the research.

The data in this research paper is collected in two ways:

\subsection{Primary Data Collection}

In this method, all the data and information were collected directly from the active Afghan women entrepreneurs and Small Scale Industries founders. The primary data was collected through the following techniques and instruments:

\subsubsection{Questionnaire}

Questionnaire was implemented to the various units in the department. A total of 25 questions were framed with multiple choices and staff were requested to choose any option based on their opinion and knowledge.

\subsubsection{Direct Interaction}

A chunk of data for the research paper was gathered through direct interaction with staff and asking them related questions. This helped not only to receive more precise information, but also increased the validity and credit of the research.

\subsubsection{Personal Observation}

Personal observation was made while working with the director of each unit at finance department and I have acknowledged that it really helped me to ensure the accuracy and the validity of the collected data.

\subsection{Secondary Data Collection}

In this method, the data, charts and graphs used in the research paper are based on both qualitative and quantitative analysis. All data in this research are collected by some of the most genuine and valid resources like journals, official website of the ministry, magazines and books to ensure the accuracy and creditability of the research paper.

Journals, websites, text books and magazines form the resources for secondary data collection which are referenced with citation at the end of the article.

\section{Literature Review}

The articles reviewed for the research are presented below:

\subsection{Dr Faitira Manuere}

Instructor at Department of Entrepreneurship and Business Management Chinhoyi University of Technology- Zimbabwe discussed the concept of "Women empowerment" that it has received much attention from researchers, government and captains of industry. There are several meanings attached to the concept of women empowerment. This literature review explores the origin of the term women empowerment as it is related to gender and equality. This literature review looks at four power perspectives that are used to explain the increasing need for women empowerment today. The related concepts of power, agency, resources and achievements are used to explain and describe the problems associated with women empowerment globally.

The theoretical underpinnings of this literature review are important for policy-makers and government the world over. Finally, the models that can be adopted to empower women, socially, economically and politically are identified and explained.

\subsection{Anne Mikkola (December 2005)}

Instructor at University of Helsinki and HECER Department of Economics explained in his paper (Role of Gender Equality in Development) that his paper reviews a broad range of micro-, macroeconomic and development 
economics literature on the impact of gender equality on economic development and growth. Stylized facts are reported as well as the results of both empirical and theoretical research. Globally, women's roles are found to be in the midst of change.

These changes may stem from technological improvement, as industrialization has made extensive home-based production obsolete and reduced the demand for children. Instead of the gendered specialization in autarkic households, contemporary specialization in the market place may have led to lower fertility and consequent shifts in women's economic roles. As historic hierarchical gender valuations appear in many different guises, adjustment to these changes pose challenges on many different levels. Overall the literature suggests that issues in gender inequality as it relates economic development fall into the categories of: values and religion, cultural restrictions and roles, legal and inheritance laws and practices, resource allocation within marriage, labor market access, education, fertility, gender specific market failures in finance, and power in decision making. "Gender equality makes our communities safer and healthier. Unequal societies are less cohesive. They have higher rates of antisocial behavior and violence. Countries with greater gender equality are more connected. Their people are healthier and have better wellbeing. [3]."

\subsection{Esther Duflo (2012)}

He mentioned in his paper that Women empowerment and economic development are closely related: in one direction, development alone can play a major role in driving down inequality between men and women; in the other direction, empowering women may be net development. Does this imply that pushing just one of these two levers would set a virtuous circle in motion? This paper reviews the literature on both sides of the empowerment- development nexus, and argues that the interrelationships are probably too weak to be self-sustaining, and that continuous policy commitment to equality for its own sake may be needed to bring about equality between men and women.

\section{Programs and Workshops for Promoting Afghan Women Capacities and Skills}

The following are some of the programs, workshops and seminars for capacity building and promoting afghan women skill and capabilities:

\subsection{Promote Program for Afghan Women}

Promote is a partnership between the Government of Afghanistan and the United States Agency for International Development to secure the gains made by Afghan women in the past decade while providing a new generation of Afghan women with the leadership skills to make vital contributions to Afghanistan's development in governance, civil society, and the economy. As the economic and business component of Promote, the Women in the Economy (WIE) activity is key to achieving the objectives of Afghanistan's Transformation Decade by empowering Afghan women from across the country to gain the skills, voices, and resources to contribute to economic growth, reduce poverty levels, and influence workplace policies in response to the needs of women in the economy.

WIE works in five regional economic zones across Afghanistan, with offices in Kabul, Herat, Mazar-i-Sharif, Jalalabad, and Kandahar.

\subsubsection{Activities}

i. 'Facilitate women's entry into decision-making roles in government service; establish an internship program for at least 3,000 educated young women to enter the Afghan Civil Service [4]."

ii. Improve the growth of women-owned businesses and businesses with a 30 percent or greater female workforce.

iii. Provide training and targeted technical assistance to address business needs; making referrals to business service providers, and help female business owners and managers to foster the growth of skilled women employees.

iv. Partner with local educational, vocational, and technical training providers to offer workplace skills development, career counseling, internships, apprenticeships, and job placement to women aged 18 and above so they can gain work experience and secure new or better positions.

v. Encourage private companies to improve the workplace environment for women and expand female staffing.

vi. Collaborate with other donors and programs to increase women's access to finance and improve the enabling environment.

\subsubsection{Expected Results}

i. 20 percent of Promote-supported businesses will move to the next level of enterprise size (for example, from small- to medium-size business).

ii. 50 percent (or more) of all Promote-supported businesses will increase revenues by more than 40 percent within two years after assistance.

iii. More than 17,000 women will receive new or better employment (including self-employment).

iv. More than 12,000 women will receive a 10 percent or greater improvement in wages or income.

v. More than 9,000 women participate in activitysupported apprenticeships or internships.

vi. Three gender-sensitive policies, regulations, or reforms will be developed to assist women in the economy.

vii. "Awarded scholarships to more than 14,733 women to train in information technology, healthcare, retail sales, customer service, and other areas [5]."

viii. "Placed 11,588 interns and apprentices in 2,524 private sector host companies across 30 provinces; more than 
half are working in healthcare and education-sectors critical to Afghans' well-being [5]."

\subsection{RECCA VII}

RECCA VII's first day focuses on role of women in economic development. The 7th Regional Economic Cooperation Conference on Afghanistan, also known as RECCA VII, has kicked off in Asghabat, capital city of Turkmenistan.

Delegation from over 40 countries are participating to discuss economic cooperation and ways to rebuild Afghanistan as the country is suffering from years of ongoing conflict. The first day of the conference focused on the role of women and their contribution to economic development. Afghan Trade and Industry Minister Humayoon Rasaw said the Afghan government is making efforts to boost women's role in the economy and said gender equality at the workplace would help increase the gross domestic product.

"To further promote women's involvement in business, the High Economic Council approved the proposal for establishment of Afghan Women's Chamber of Commerce and Industries," [6]. Chamber of Commerce and Industry of Afghanistan General Director Atiqullah Nasrat: "We hope that the focus will help women-owned enterprises in the RECCA region to interact with each other and improve their access to regional and international markets, and to learn best practice in order to contribute job creation and economic growth in their economies." [7]

Afghan First Lady Rula Ghani said "women participation in the Afghan economy is slowly increasing. Afghanistan aims to create a platform that would encourage and facilitate regional and inter-regional economic cooperation through the RECCA conference, which was launched in 2005.” [8]

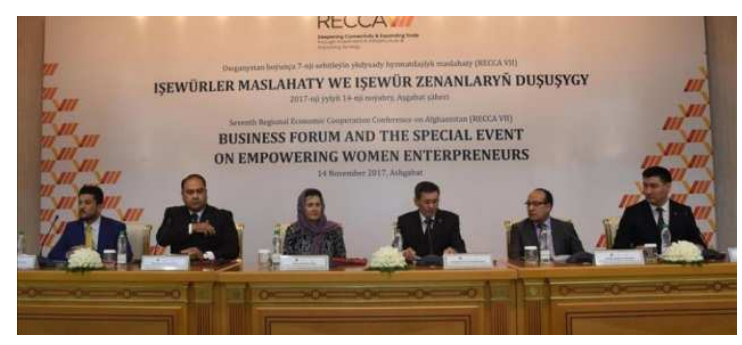

Figure 1. The RECCA VII summit held in Turkmenistan.

\subsection{WEE-NPP}

Another program for empowering the role of women in economic development of Afghanistan, the Government of the Islamic Republic of Afghanistan (GOIRA) launched the Women's Economic Empowerment National Priority Program (WEE-NPP) on March 8th, 2017. The WEE-NPP forms the third pillar of the GOIRA's Gender Strategy which is encompassed in the broader Afghanistan National Peace and Development Framework (ANPDF) - the country's fiveyear development plan for 2017-2021. [9]

The WEE-NPP aims to build poor women's capacity to strengthen the economy of their households, communities, and the entire nation. It is structured as an umbrella program (rather than a stand-alone project/operation) that would operate through over a dozen line ministries (through ongoing or pipeline projects) and coordinated through a Program Coordination Office (PCO) in the Ministry of Labor, Social Affairs, Martyrs and Disabled (MOLSAMD). The latter would in turn provide startup technical and financial resources to support women-owned businesses, and development of job skills, and financial literacy.

The program would further help create an enabling environment for WEE through policy and planning reforms that will remove legal barriers to women's economic participation; streamline and reduce regulatory barriers to women's involvement in marketing; and improve the quality and use of gender statistics for planning 8. The WEE-NPP builds upon and complements other initiatives of the GOIRA.

\section{Challenges and Obstacles Faced by Afghan Women}

Breaking centuries of tradition; the today's Afghan woman has not only embraced a life in the corporate world but has also begun to make her moves beyond a corporate career and into Entrepreneurship. While a corporate career gives her the financial independence and growth to substantiate her abilities, being an Entrepreneur takes her beyond that and into a world where not only does she get an opportunity to carve a notch for herself but also make a difference.

What stops them from taking on that journey? Why is it that despite the change in numbers we do not see as many women on the Entrepreneurial map? And whether we like it or not, why do most perceive potential failures for women who do take the plunge? Many reasons contribute to this but when you give it a though you realize that most of the reasons that stand out usually stem from two important factors - The society and Security/safety.

\subsection{Lack of Job Opportunities}

Up from 31 percent in 2008 to 35 percent in 2009, unemployment is cited as the second biggest problem Afghan women face. A separate study indicated that only a quarter of government positions are occupied by women. Public awareness programs that reinforce the Islamic notion that all men and women should have access to knowledge in order to mitigate discrimination against women are critical. Such programs could be implemented by religious scholars and clergies, civil society organizations, or government institutions.

Without safety, however, improvements for Afghan women are remote. The international community must work alongside the Afghan government to restore security, especially for women and girls so that they can gain greater access to education and play a larger role in stabilizing their country. [10]

\subsection{Illiteracy and Education}

Afghanistan's literacy rate is very low compared to other 
countries. In Afghanistan, only 23.5 percent of the population above 15 years old is literate, while the rate for women is even worse at 12.6 percent. At 36 percent, Afghanistan's enrollment of girls in primary schools is low compared with 90.4 percent in Iran, 67 percent in Saudi Arabia, and 62 percent in Pakistan.

In spite of such low figures, Afghanistan has experienced a few major achievements in the education sector for women, including the adoption of certain guarantees in the constitution (Article 44) regarding development of balanced education for women; the enrollment of 2.2 million girls in primary schools (unprecedented in Afghanistan's history); and permission to establish higher education institutes in specialized fields and basic literacy schools (Article 46). However, many obstacles lie ahead, such as discrimination on the basis of sex, patriarchy, and male domination in the society; local traditions and discrimination against women's education; lack of female schools in villages; lack of proper education infrastructure; lack of personal security; and lack of female teachers, to name a few. There are also sociocultural beliefs that consider education unnecessary or even hazardous for women, further preventing girls from attending schools. Even in seminaries, the number of female students is very low due to lack of interest in women's education and lack of female religious teachers.

\subsection{Traditional Mindsets}

When a friend once announced that she would like to quit her job and set up her own Art and Design business, instead of a pat on the back or a hearty congratulations, she got a raised brow and a question that broke her confidence "You are a girl, what will you be able to do"? While a lot many women are breaking the shackles and moving out of their homes to work, setting up businesses is still perceived to be a Man's domain.

\subsection{Limited Funding}

Not all business people are fortunate enough to have an investor or financier for their business. Some have to bootstrap their entrepreneurial ventures, rely on credit cards or raise capital on their own. Women's businesses are among the leading ventures that lack financial support. It is also common for women to be denied loans because of gender and cultural biases - many institutions tend to fund maleowned businesses. [11]

\subsection{Lack of Financial Support}

Not all business people are fortunate enough to have an investor or financier for their business. Some have to bootstrap their entrepreneurial ventures, rely on credit cards or raise capital on their own. Women's businesses are among the leading ventures that lack financial support. It is also common for women to be denied loans because of gender and cultural biases - many institutions tend to fund male-owned businesses.

\subsection{Aggression and Assertiveness}

Most Afghan women are known to be extremely adaptive but the aggression and assertiveness that is required to get their need across has not been a known characteristic in them. However this is once aspect that is changing with more and more women from urban areas who are educated and have an exposure to society taking the initiative to start their own business.

\subsection{Networking}

An important aspect of running your own business is the ability to socialize within the Entrepreneurial network to build contacts and win customers but very few Afghan women step out of their comfort zones to do so. If they do socialize, it is limited to the work they need to get done and not to build relationships. The implication of this is directly on the extent of visibility they have in the market and on the perception they build.

\subsection{Prioritization Expectations}

Societal expectations that whatever a woman does, she should always prioritize her family over everything else can prove to be a big deterrent for those running their own show. Most women bow down to the pressure instead of working out a win-win situation.

A successful woman entrepreneur once pointed out an easy solution to this dilemma; she worked out a solution where she and her husband shouldered their domestic responsibilities equally thus giving her enough time to focus on her work. Understanding that men are also quite capable of handling family responsibilities and making that a reality can go a long way in resolving this obstacle.

\subsection{Safety and Security}

In today's times, probably this is the biggest obstacle for women in Afghanistan. The security blanket is at its thinnest thus making women hesitate to take on roles that demand long hours and interactions with a world of strangers. The rise of social crime and the need for safety pushes everything down the priority list when there is a demand to spend late hours at getting work going.

While urban women are taking the plunge after much thought, the silver lining is when women from rural areas turn Entrepreneurs in their own small ways with things such as opening a small grocery store or something as simple as rearing cows to sell dairy products. A small step in the rural world can be a huge motivation in the urban one.

Despite these bottlenecks that most urban women face in Afghanistan, there are many who have risen above them and built successful businesses. Communicating with the family and thinking the business idea out with a long term sustainable plan can act as a key to succeed. Most important of all, developing an attitude to persevere despite all odds goes a long way in being successful.

\section{Conclusion}

The role of women in economic development of Afghanistan is an undisputable subject. In 4 decades of war, they were the 
most vulnerable part of the society; now they have a real chance to take part in making Afghanistan a better place.

Their role in economic development of Afghanistan is supported by both inter-governmental organizations and foreign countries agencies by providing fund, programs and workshops for creating awareness amongst women, upgrading the skills and abilities of them, provide calm and secure environment and above all assisting them to take role directly in economic development of Afghanistan.

Some of the main programs and workshops for women empowerment were mentioned in details with accurate numbers from trustworthy resources. The data and numbers in this research paper is conducted based on both primary and secondary data from reliable and genuine resources

Women are perhaps the most essential part of the society which are playing a vital role in economic development of beloved Afghanistan, a wounded country which is still struggling from various factors.

\section{Recommendations}

After wrapping up the research and collecting of all required data and analysis, the following points are hereby recommended for promoting the role of Afghan women in economic development of Afghanistan.

\subsection{Develop and Promote Female Role Models}

Develop awareness of female leaders in politics, business, academia, and the various economic sectors in Afghanistan and outside the country. Dialogue should strive not only to build women's access to tools that support their participation in the economy, but also to reach out to both men and women to help them understand how Afghanistan can overcome a culture in which women are valued less than men. Women must be empowered and the enabling environment must be changed. Impact: Increased awareness among men and women that women can succeed in Afghanistan and around the world.

\subsection{Create Business Networks and Linkages for Women}

Provide targeted support to associations, online communities, and business organizations for women in order to increase their networks and foster the exchange of business-related information targeted at internal and external market access and the skills to run a business. The networks would also serve to increase the visibility of successful women, create a business mentality among women, and provide advocacy for members. Develop sections within existing business organizations (ACCI, EPAA, and AISA). Impact: Increased networking, understanding of business, and advocacy for efforts that address women's needs.

\subsection{Develop a Strategy for Economic Empowerment that Extends to the Provinces}

Extend support for women's economic development and empowerment into the provinces in a holistic manner. Impact: Increased ability for business women to utilize a skilled labor base and uplift women outside of Kabul. Increased ability for women in the provinces for income generation. Increased knowledge sharing and demonstration of empowerment flowing from the capital. [12]

\subsection{Create an Awareness of Successful Women at Work and the Benefits for the Family and Society}

Work with media organizations to create radio and television content that features examples of women in business-for example, through dramas, talk shows, and documentary style features. Impact: Expanded ideas of women's roles and capabilities in economic life among men and women.

\subsection{Provide a Business Space for Female Business Owners}

Provide incentives and dedicate space in an industrial park for female business owners or develop an industrial park dedicated to women with preferential incentives (lower rent, utilities, tax holiday). Individual factories could also be "zoned" as preferential. Consider use of surplus military bases dedicated as zones for women depending on social acceptance. Impact: Benefits for women in business, including space and electricity.

\section{References}

[1] Meet a New Generation of Women in Kabul. National Geographic. 21 October 2014.

[2] Bayer, Rouse, Amanda, Cecilia (Fall 2016). "Diversity in the Economics Profession: A New Attack on an Old Problem".

[3] https://www.vic.gov.au/benefits-gender-equality.

[4] https://www.usaid.gov/news-information/fact-sheets/promotewomen-government.

[5] https://www.dai.com/our-work/projects/afghanistan-womenin-the-economy.

[6] Humayoon Rasaw, Afghan Trade and Industry Minister, Nov 152017.

[7] Atiqullah Nasrat, Chamber of Commerce and Industry of Afghanistan General Director, Nov 152017.

[8] Rula Ghani, First Lady of Afghanistan, 2017.

[9] https://projects.worldbank.org/en/projects-operations/projectdetail/P163267?lang=en

[10] Najla Ayubi, Asia Foundation, Jan 272010.

[11] https://www.forbes.com/sites/margueritacheng/2018/10/31/8major-challenges-women-face-in-business/\#513acf4f6461

[12] "Economic empowerment strategies for Afghan women report”, USAID, March 2012. 